\title{
FEDERAL-STATE RELATIONS UNDER THE BANK HOLDING COMPANY ACT OF 1956
}

AMERICAN banking structure reflects a continuing reconciliation of federal and state interests in the control of monetary institutions. As a "necessary and proper" adjunct to its Article I powers, ${ }^{1}$ Congress maintains national fiscal policy through the agency of federally chartered banks ${ }^{2}$ and through the operations of the Federal Reserve System. ${ }^{3}$ Although able to pre-empt the field, the national government has left much of banking regulation to local control." It has allowed the states to charter banks and to enact banking laws not in conflict with federal legislation." Further, recognizing the facility with which

1. The constitutional basis for congressional monetary control derives from "the great powers to lay and collect taxes; to borrow money; to regulate commerce; to declare and conduct a war; to raise and support armies and navies," as supplemented by the necessary and proper cause, U.S. Consr. art. I, § 8, cl. 18. McCulloch v. Maryland, 17 U.S. ( 4 Wheat.) 316, 407 (1819). See Legal Tender Cases, 110 U.S. 421 (1884) ; Osborn v. United States Bank, 22 U.S. (9 Wheat.) 738 (1824); Wyatt, Federal Banking Legislation, in Banking Studies 39-46 (Federal Reserve System ed. 1941). See also note 4 infra.

2. First Nat'l Bank v. Anderson, 269 U.S. 341, 347 (1926) ; Easton v. Towa, 188 U.S. 220, 229-30 (1903). See Attorney Gen. ex rel. State Banking Comm'r v. Michigan Nat'l Bank, 29 Mich. 417, 299 N.W. 129 (1941) ; 7 Michie, Banks and Banking c. 15, § 1 (2d ed. 1944) (hereinafter cited as MICHIE). The public functions of national and federal reserve banks include issuing currency; holding reserves of commercial banks and public funds; regulating the supply, availability and interest rate of money; and generally serving as the fiscal agents of the government. See Sterner \& Shapro, Money and BankING 245-49 (3d ed. 1953). The present system of national banks was created by the $\mathrm{Na}$ tional Banking Act of 1864, REv. STAT. $\$ \$ 5133-56$ (1875). Statutory provisions governing national banks are found in 12 U.S.C. $\$ \$ 21-213$ (1952). Federal Reserve regulations also apply since national banks must be members of the Federal Reserve System. 38 STAT. 252 (1913), as amended, 12 U.S.C. \$ 501a (1952).

3. The Federal Reserve Act, 38 STat. 251 (1913), as amended, 12 U.S.C. $\$ \$ 221-522$ (1952), was enacted "to provide for the establishment of Federal reserve banks, to furnish an elastic currency, to afford means of rediscounting commercial paper, to establish a more effective supervision of banking. ..." 38 STAT. 251 (1913). See, generally, Board of Governors of the Federal Reserve System, The Federal Reserve Systen-Its Puripases ann Functions (3d ed. 1954); Banking Studies (Federal Reserve System ed. 1941 ).

4. Commentators find each of a number of Article I powers itself sufficient to authorize congressional regulation of banking to the exclusion of state control. Included are the powers to regulate interstate commerce, U.S. Const. art. I, $\$ 8, \mathrm{cl} .3$, to lay and collect taxes, $i d$. cl. 1 , or to coin money and regulate the value thereof, id. cl. 5 . See Comment, Constifutionality of Exclusive Federal Control over Commercial Banking, 43 YALE L.J. 454 (1934); Note, The Federal Taxing Power as a Means of Establishing a Unified Banking System, 46 Harv. L. Rev. 143 (1932). See also Anderson, Federai. axd State Lontrol of Banking 339-483 (1934).

5. A state has general regulatory powers to control the banks it charters. See 1 MicunE, ch. 1, $\$ \$ 1-6$. The federal banking system exists independent of state regulation, for the National Banking Act, see note 2 supra, constitutes "by itself, a complete system 
a bank might shift between federal and state systems, ${ }^{6}$ Congress has sought to preserve the existing dual structure by making national and state bank charters appear equally attractive. ${ }^{7}$ Dominant federal control has been exerted over both state and federal banks, however, when necessitated by the inadequacy of state regulation or required in the interest of national uniformity. Thus, in establishing a single currency, federal law has precluded state issue. ${ }^{8}$ And aware that state regulation could not afford the needed protection. Congress established the Federal Deposit Insurance Corporation to guarantee bank deposits. $^{9}$

The operations of bank holding companies, corporations which may own and manage banks in many states, constitute another area in which state con-

for the establishment and government of National Banks." Cook County Nat'1 Bank v. United States, 107 U.S. 445, 448 (1882). State law is applicable to national banks, however, where it does not interfere with the purposes of their creation, tend to impair their efficiency as federal agencies, or conflict with the paramount authority of the United States. Davis v. Elmira Sav. Bank, 161 U.S. 275, 283 (1896) ; Jennings v. United States Fidelity \& Guaranty Co., 294 U.S. 216, 219 (1935).

6. A state bank may shift to a national charter upon approval of the Comptroller of the Currency and upon the vote of the holders of 51\% of the stock. REv. STAT. \$ 5154 (1875), as amended, 12 U.S.C. $\$ 35$ (1952). But conversion in contravention of state law will not be allowed. Ibid. Thus a state may establish its own requirements for conversion. E.g., MICH. STat. ANN. \$ 23.866 (Supp. 1955) (two-thirds stockholder assent required). But state restrictions on conversion may be easily evaded by liquidation prior to conversion. See, e.g., Ohio Rev. Cone Ans. § 1103.36 (Page Supp. 1956). See also S. ReP. No. 1104, 81st Cong., 1st Sess. 2 (1949) ; Maryland v. National Bank, 33 Md. 75 (1870).

Similar provisions govern merger and consolidation. 44 Sxar. 1224 (1927), as amended, 12 U.S.C. $\S 34 \mathrm{a}$ (1952) ; 66 STAт. 599 (1952), 12 U.S.C. $\S 34 \mathrm{~b}$ (1952); 64 Stat. 455 (1950), as amended, 12 U.S.C. $\$ \$ 214-214 c$ (Supp. III, 1956).

7. E.g., national banks were granted branching privileges equivalent to those of state banks. 44 Stat. 1228 (1927), 48 STat. 189 (1933), 12 U.S.C. $\$ 36$ (1952). And states may not tax national bank shares at a higher rate than competing moneyed capital, REv. STAT. § 5219 (1875), as amended, 12 U.S.C. § 548 (1952) ; First Nat'l Bank v. Hartford, 273 U.S. 548 (1927). This policy is manifest in the grants to national banks of power to act as fiduciaries, 38 STAT. 262 (1913), as amended, 12 U.S.C. $\$ 248(\mathrm{k})$ (1952); to switch charters, see note 6 supra; to give liens on assets to secure deposits of state funds, 46 STAT. 809 (1930), as amended, 12 U.S.C. $\$ 90$ (1952) ; Lewis v. Fidelity \& Deposit Co., 292 U.S. 559, 564 (1934); to pay no greater interest on time and savings deposits than state banks, 44 STAт. 1233 (1927), as amended, 12 U.S.C. \& 371 (1952); and to establish certain branches if state capital requirements are met, 44 Star. 1227 (1927), as amended, 12 U.S.C. \$ 51 (1952). And see 48 STAт. 181 (1933), as amended, 12 U.S.C. $\$ 371 \mathrm{a}$ (1952), forbidding national banks to pay interest on demand deposits except on state or municipal funds where required by state law.

8. 14 STAT. 146 (1866), as amended, 26 U.S.C. $\$ 1900$ (1952), imposed a prohibitory $10 \%$ tax on the circulation of state bank notes. It was enacted to provide monetary uniformity and to foster the newly-created national bank system. Veazie Bank v. Fenno, 75 U.S. (8 Wall.) 533 (1869) (such restriction of state banking agencies constitutional exercise of Congress' paramount authority over all forms of money). See Comment, Constitutionality of Exchisive Federal Control over Commercial Banking, 43 YALE L.J. 454, 464 (1934).

9. 48 Stat. 168 (1933), as amended, 12 U.S.C. $\S 1811$ (1952). See 47 HaRv. L. Rev. 325, 331 (1933). 
trol has proved inadequate. Although an efficient business organization, the bank holding company has exhibited characteristics inconsistent with principles of sound banking. ${ }^{10}$ Its structure has permitted parent corporations to "dump" overvalued securities upon subsidiary banks, and to obtain improperly secured loans for non-banking corporate affiliates. ${ }^{11}$ Moreover, by fostering concentration of ownership, holding company organization has substituted absentee control for the unit banking system commonly believed to be more attuned to local interests and thus better equipped to serve local needs. ${ }^{12}$ Accordingly, many states have attempted to restrict the holding company form of group banking. ${ }^{13}$ Some have limited the power of domestic corporations to own bank stock. ${ }^{14}$ Others have extended their branch banking laws, hoping so to curb both foreign and domestic holding companies. ${ }^{15}$ But the federal

10. As a unified, centralized organization, a bank holding system can efficiently supply affiliate banks with capital obtained from its wide market for stock issues; with traine'd management personnel attracted to the corporation because of the broad opportunities available; and with services such as investment advice, trust and foreign departments, centralized accounting, auditing and purchasing, group insurance, and pension systems. Hogenson, The Economics of Group Banking 139-45 (1955). See, e.g., Hearings Before a Subcommittee of the Senate Committee on Banking and Currency, 84th Cong., 1st Sess., pt. 1, at 301-03 (1955) ; Steiner \& Shaprro, Money and Banking 97-98 (3d ed. 1953).

11. See, c.g., Hearings Before the Senate Committee on Banking and Currency, 83d Cong., 1st Sess., pt. 1, at 53-55, 104-16 (1953) ; id., 73d Cong., 2d Sess., pts. 11-12, passin (1934) ; H.R. Rep. No. 609, 84th Cong., 1st Sess. 4-5 (1955).

12. This attitude was verbalized throughout the congressional hearings preceding the Bank Holding Company Act of 1956. See id. at 5-6. For legislative history, see 2 U.S. Code Cong. \& Ad. News 2482, 2484-86 (1956).

13. For recent legislation see Ill. ANN. STat. c. 16ז/2, $\$ \$ 64-68$ (Smith-Hurd Supp. 1956), note 51 infra; N.Y. Sess. Laws 1957, c. 806 . For less recent legislation see, e.g., MIss. Code ANN. \$ 5196 (Supp. 1954) (state comptroller has general suspension and regulatory powers over corporations formed to hold bank stock); W. VA. CODE ANN. $\$ 3220$ (1955) (purchases of stock in bank as speculation or to perfect control unlawful).

14. E.g., IrL. ANN. Stat. c. 32, § 157.5 (g) (Smith-Hurd Supp. 1956) (corporation may not hold $15 \%$ or more of stock of two or more banks) ; MicH. STAT. ANN. $\$ 21.101$ (Supp. 1955) (corporation may not hold bank stock unless acquired in reorganization of the bank); WASH. REv. CODE $\$ 30.04 .230$ (Supp. 1956) (corporation may not hold more than $25 \%$ of bank's stock). See also notes 13 supra, 49 infra.

15. The typical anti-branching law prohibits a bank from engaging in business at more than one office. See, e.g., ILI. ANN. STAT. c. 16/2/2, \$ 106 (Smith-Hurd Supp. 1956); Tex. Rev. CIv. Stat. ANn. art. $342-903$ (1956). To regulate holding companies through branching laws, the enforcing authority must show that the relationship between the units is so close that their separate corporate entities can be disregarded, or that a principalagent relation exists. Hearings Before the House Committee on Banking and Currency, 84th Cong., 1st Sess. 195 (1955). See Castle, Ilz. Art'y Gen. Ops. 34 (1953), for the unchallenged opinion of the Illinois Attorney General that a bank which organizes affiliates whose stock it planned to hold in trust would violate the branch banking law. But the Illinois branch law does not prevent penetration by typical holding companies since no more than stock ownership by such companies can be shown. Hearings, supra at 201, CASTLE, op. cit. supra at 88 . Texas has had more success in curbing holding companies through branch laws. Hearings, supra at 160, 200-01. See HogENson, op. cit. sufra note 10 , at $191-92$. 
government had done little more than supervise holding company groups embracing national or Federal Reserve "member" banks. ${ }^{16}$ The recent growth of bank holding companies increasingly revealed the shortcomings of existing controls and the need for more stringent federal measures. ${ }^{17}$

In the Bank Holding Company Act of $1956 .{ }^{18}$ Congress seeks to regulate the excess concentration and unsound practices engendered by this form of group banking. ${ }^{10}$ The act defines a bank holding company as a corporation owning at least twenty-five per cent of the voting stock in two or more banks. ${ }^{2 n}$ To minimize the undue reciprocal competitive advantages inherent in equity union between a bank and non-banking corporations, holding companies are required to divest themselves of most non-banking subsidiaries. ${ }^{21}$ They may retain only those "financial, fiduciary, or insurance" affiliates which the Board of Governors of the Federal Reserve System determines to be "closely related" to banking. ${ }^{22}$ Transfers of funds from affiliate banks to parent holding companies are prohibited so that subsidiary banks cannot be plundered by stock dealings or manipulation of loans. ${ }^{23}$ But most important, the act limits holding company expansion. Before an existing holding company may acquire the assets of or stock in a bank, or before a new holding company may be formed.

16. The Banking Act of 1933, 48 STAT. 162 (1933) (codified in scattered sections of 12 U.S.C.), requires a holding company to obtain a voting permit from the Federal Reserve Board before it can vote its stock in a national or other member bank. To obtain the permit a holding company has to submit to examinations, make financial reports and maintain certain reserves of marketable assets. 48 STAT. 186 (1933), as amended, 12 U.S.C. $\$ 61$ (1952). A corporation can easily avoid these restrictions by limiting its holdings to non-member banks, by not voting the bank stock or by maintaining control through friendly interests. See Comment, 1 STAN. L. Rev. 658, 665-66 (1949). Chairman Martin of the Board of Governors concluded: "In effect, therefore, regulation is largely voluntary on the part of the holding company." Hearings, supra note 15 , at 13 .

17. See, e.g., 102 CoNg. REc. 6858-60 (1956) (statement of Senator Douglas (I11.)) ; Comment, 1 Stax. L, Rev. 658 (1949).

18. 70 STAт. 133 (1956), 12 U.S.C.A. $\$ \$ 1841-1848$ (1957). For discussions of the act generally, see Comment, 9 Stan. L. Rev. 333 (1957) ; 31 St. John's L. Rev. 146 (1956).

19. H.R. Rep. No. 609, 84th Cong., 1st Sess. 1-6 (1955). See notes 11-12 supra.

20. 70 Star. 133 (1956), 12 U.S.C.A. $\$ 1841$ (1957). Exceptions to this basic definition are recognized. Ibid.

21. 70 Star. 135 (1956), 12 U.S.C.A. \$ 1843 (1957). See, e.g., Hearings, supra note 10 , at 64,124 . Divestment, of course, is also designed to protect depositor's' funds from the risk of improper investment in the non-banking holding company affiliates. See, c. $/$., H.R. ReP. No. 609, 84th Cong., 1st Sess. 7 (1955) ; Hearings, supra note 15, at 509.

22. The holding companies are given two years, which the Board may extend to five, to divest themselves of prohibited non-banking subsidiaries. 70 STAT. 135 (1956), 12 U.S. C.A. $\$ 1843$ (1957).

23. 70 Stat. 137 (1956), 12 U.S.C.A. \$ 1845 (1957). See H.R. ReP. No. 609, S4th Cong., 1st Sess. 4-5 (1955). "Cross-stream" transactions (transfers of funds from bank to non-banking affiliates) are also prohibited. 70 STAT. 137 (1956), 12 U.S.C.A. \$ 1845 (1957). However, the act does not prohibit "downstream" transactions (transfers from parent to bank) on the premise that the added security given the bank outweighs the disadvantage to its independent competitors which cannot secure funds so easily. Comparc, e.g., Hearings, supra note 15, at 131, 235, with, e.g., Hearings, supra note 10, at 64, 124. For other exceptions, see 70 STAT. 137 (1956), 12 U.S.C.A. \$ 1845 (1957). 
specific federal authorization must be received from the Board of Governors. ${ }^{24}$ . Ind this authorization can be given only after the transaction has been considered with respect to its effect on banking concentration generally, and more specifically, with respect to its effect on the convenience, needs and welfare of the area concerned. ${ }^{25}$

In limiting holding company expansion, Congress has reconciled imposition of national control with preservation of state regulation. The federal-state balance is defined by two sections of the act based on the premise that limitations on this expansion should ultimately be geared to state policy. Section 3 (d) restricts Board discretion over interstate transactions: expansion into a state may be approved only where the state has legislated expressly to permit foreign corporate acquisition of domestic banks. ${ }^{26}$ And section 7 preserves to the states the powers maintained over banks and holding companies prior to passage of the act. ${ }^{27}$ By thus preserving and expanding their authority, Congress has allowed the states to implement a policy for effective control of banking concentration. Yet the interplay between state regulation and federal law raises questions concerning the proper interpretation and enforcement of state policy.

Standing alone, the preservation of powers in section 7 gives the states only formal authority. State control of branch banking-the practice of conducting banking operations at more than one office-has been of little effect in limiting concentration. Although the McFadden Act extended state regulation of branching to national banks by adopting state standards as the governing fed-

24. 70 STAT. 134 (1956), 12 U.S.C.A. $\$ 1842$ (a) (1957). On receiving an application for approval involving a national bank, the Board must notify the Comptroller of the Currency. In the case of a state bank, the appropriate state supervisory authority must be notified. A hearing is mandatory only if the notified authority disapproves the transaction. 70 Stat. 134 (1956), 12 U.S.C.A. \$ 1842(b) (1957). See Note, 9 Stan. L. Rev. 333, 342 (1957). Approval is also required for merger and consolidation of holding companies. 70 Sтsт. 134 (1956), 12 U.S.C.A. \$ 1842(a) (1957). For acquisitions which may be allowed without Board approval, see note 48 infra.

25. 70 STAT. 135 (1956), 12 U.S.C.A. \$ 1842 (c) (1957).

26. Id. \& 1842(d). Section 3(d) provides:

"Nutwithstanding any other provision of this section, no application shall be approved under this section which will permit any bank holding company or any subsidiary thereof to acquire, directly or indirectly, any voting shares of, interest in, or all or substantially all of the assets of any additional bank located outside of the State in which such bank holding company maintains its principal office and place of business or in which it conducts its principal operations unless the acquisition of such shares or assets of a State bank by an out-of-State bank holding company is specifically authorized by the statute laws of the State in which such bank is located, by language to that effect and not merely by implication."

27. 70 SтAт. 139 (1956), 12 U.S.C.A. $\$ 1846$ (1957). Section 7 provides:

"The enactment by the Congress of the Bank Holding Company Act of 1956 shall not be construed as preventing any State from exercising such powers and jurisdiction which it now has or may hereafter have with respect to banks, bank holding cumpanies, and subsidiaries thereof." 
eral law, ${ }^{28}$ the impact of the resulting controls has been avoided by resort to holding company structure $;^{29}$ and the local sovereign's inherent power over domestic corporations has been equally ineffective in limiting bank growth. True, a state has wide discretion to restrain the conduct of foreign corporations doing business within its borders ${ }^{30}$ as well as virtually unlimited power to regulate the conduct of an organization incorporated under its laws. ${ }^{31}$ Thus it may control the activities of foreign holding companies doing business locally as well as those of domestic banks and holding companies. But most foreign holding companies are beyond its reach; for a corporation merely owning state bank stock does not come within the definition of doing business. ${ }^{32}$ Moreover, except with regard to tangential matters and its indirect control over branching, a state is without power to regulate national banks. ${ }^{33}$ This dual exemption

28. 44 Stat. 1228 (1927), as amended, 12 U.S.C. \& 36 (1952). The Banking Acts of 1.933, 48 Stat. 189, and 1935, 49 STAт. 708, amplified the McFadden Act and continued its principles. Congressional adoption of state law as a standard was effected by granting branch powers to national banks to the same extent that the state in which the national bank was located granted them to state banks. The 1956 act was considered a logical continuation of the principles of the McFadden Act. 102 CoNG. Rec. 6860 (1956) (Senator Douglas (III.), introducing $\S 3(\mathrm{~d})$ as an amendment).

29. Hearings, supra note 10, at 107; see Cartinhour, Branch, Grout and Chain Banking 120-27 (1931); Comment, 1 Stan. L. Rev. 658, 662 (1949).

30. See, generally, 17 Fletcher, Cyclopedia of CoRporations $\$ \$ 8386-8445$ (perm. and rev. ed. 1933) (hereinafter cited as FLETCHER). Conditions repugnant to the Constitution may not be imposed. E.g., Terral v. Burke Constr. Co., 257 U.S. 529 (1922) (state may not require waiver of the right to resort to federal courts) ; Brust v. First Nat'l Bank, 184 Wis. 15, 198 N.W. 749 (1924) (state powerless to prohibit national bank from doing business within the state) (dictum).

31. Ashley v. Ryan, 153 U.S. 436, 441 (1894); see Louis K. Liggett Co. v. Lee, 288 U.S. 517, 544-45 (1933) (dissenting opinion); 1 FLETCHER $§ 114$.

32. Cannon Mfg. Co. v. Cudahy Packing Co., 267 U.S. 333 (1925) ; People's Tobacco Co. v. American Tobacco Co., 246 U.S. 79 (1918) ; Fergus Motors, Inc. v. StandardTriumph Motor Co., 130 F. Supp. 780 (S.D.N.Y. 1955). The parent company is subject to state regulation only if the corporate entities can be viewed as one or if agency can be established. See cases collected Annot., 18 A.L.R.2d 187 (1951). But see Bankers' Holding Corp. v. Maybury, 161 Wash. 681, 297 Pac. 740 (1931) (foreign corporation held subject to state regulatory power because organized for specific purpose of holding stock: in and managing domestic corporations). Bankers' Holding Corp. is dubious authority, however. See statement of the Attorney General of Washington:

"[T] he case was in a minority of one at the time of decision ... was the subject of critical comment at the time, 40 YALE L.J. 1322, and ... no court, including the Washington Supreme Court, has cited the case as authority for the proposition which forms the holding of the case."

Hearings, supra note 15 , at 333 . There were repeated references during the Hearings to states' inability to regulate foreign holding companies. See, e.g., id. at 113, 164-65, 175, 362.

33. Congress has yielded control over branch powers. See note 28 stipra. Under the principles set out in note 5 supra, state law regulates many aspects of national bank operation, such as the construction of contracts, transfer or escheat of property, creation of debts and liability to suit. 7 M IснIE c. $15, \S 5$. See, e.g., Lewis v. Fidelity \& Deposit Co., 292 U.S. 559, 566 (1934) ; McClellan v. Chipman, 164 U.S. 347 (1896). But management and control of national banks are beyond state authority. Thus states may not regulate 
from local rule has rendered nugatory any extensive use of the sovereignty powers. With foreign corporate acquisition of national banks not subject to limitation, any stringent state regulation would impair the utility of the state banking system rather than seriously deter concentration. State banks could avoid restrictions placed upon their acquisition by reincorporating under a national charter; and in view of the recent tendency toward interstate union, such shifts would be likely. ${ }^{34}$ Since domestic holding companies cannot avoid state limitations, restricting their expansion would place them at a serious competitive disadvantage with foreign corporations.

However, section 3 (d) gives the states the comprehensive authority required for effective and equitable control of holding company expansion. The section allows each state to prevent union between foreign holding companies and local state or federal banks. Because foreign penetration is thus limited, local supervision of domestic banking growth can no longer be circumvented by state bank defection to the national system. And with the advent of general holding company control, branch banking regulations will become increasingly important. Only by integrating its controls over holding companies and branch banking, may a state effect the expansion policy it finds best suited to domestic needs. ${ }^{35}$ New York, for example, has been quick to recognize and employ the authority delegated by section $3(\mathrm{~d})$; it has recently enacted restrictive legislation to forestall several significant prospective transactions. ${ }^{36}$

matters such as liquidation, stockholder liability and director's duties. 7 MrCHIE c. 15, § 5. See, e.g., Franlslin Nat'l Bank v. New York, 347 U.S. 373 (1954) ; Forrest v. Jack, 294 U.S. 158, 162 (1935) ; note 5 supra.

34. See note 6 supra. In particular, Transamerica Corporation, which had banks in 5 states at the end of 1954, Hearings, supra note 10, at 52, had expanded into 11. states by the end of 1956. N.Y. Times, March 19, 1957, p. 47, col. 6. As of Dec. 31, 1954, Northwest Bancorporation had banks in 7 states; First Bank Stock Corporation in 4 states; First Security Corporation in 3 states; General Contract Corporation in 3 states. H.R. REP. No. 609, 84th Cong., 1st Sess. 4 (1955) ; Hearings, supra note 10, at 51-52; 102 CoNG. REc. $6 \$ 58-59$ (1956).

35. Absent such integration, a foreign company holding one bank in the state could expand by simply branching that bank. See text at note 40 infra; Mr. A. Schapiro \& Co., The Triple Banking System 27 (1956).

36. N.Y. Sess. Laws 1957, c. S06. New York is interested not so much in blocking Lank holding companies per se, as in preserving its law limiting branch banking to the nine banking districts into which the state has been divided. N.Y. BANkING LAW $\$ 105$. The branch law has stopped upstate expansion by the giant New York City banks. N.Y. Times, Nov. 11, 1956, $\$ 3$, p. 1, col. 1. Exerting its power preserved by $\S 7$ of the federal act, supra note 27 , New York forbids a company organized or doing business within the state to acquire more than $25 \%$ of the stock of each of two or more banks located in different banking districts. However, a holding company may be freely formed within a banking district. The legislation was precipitated by a proposed holding company union between the First National City Bank of New York City and the Westchester County Trust Co. located in different banking districts. N.Y. Times, Nov. 11, 1956, § 3, p. 1, col. 1. New York imposed these restrictions anticipating widespread hurdling of the district lines by city banks following the population shift to the suburbs. Compare N.Y. Times, Mar. 28, 1957, p. 43, col. 5, aviti N.Y. Times, Nov. 11, 1956, § 3, p. 1, col. 1. However, negotiations toward holding company structure continue, with the banks raising the con- 
While section 3(d) increases the effectiveness of local policy by requiring that the Board disapprove expansion into a state which has not expressly authorized foreign corporate acquisition of domestic banks, it does not adequately set forth the criteria for determining the situs of a holding company, and thus its "foreign" character. The section defines situs as "the State in which such bank holding company maintains its principal office and place of business or in which it conducts its principal operations. . ."3t Under the interpretation most often advanced, "place of principal operations" would mean the state in which the greatest number of subsidiary banks is located. ${ }^{38}$ Where such state is not the same as that of the corporation's principal office, one of the two states would have to be chosen as the permanent section 3(d) residence. Although Congress did not expressly consider whether this choice should lie with the Board or the holding company, the committee hearings indicate that the selection could be made by either and that the Board would issue regulations declaring which alternative would be utilized. ${ }^{39}$ However, allowing the holding company to make this choice might enable it to expand in the chosen situs unfettered by domestic control. The provisions of section 3 (d) would not be applicable since the expanding company would be domestic rather than foreign. Moreover, should the corporation neither be chartered nor conduct business other than mere ownership of bank stock in the designated state, the state's section 7 powers would be equally useless. Of course, the latter requirement could be met only if the corporation chose the state where its subsidiaries were most numerous rather than the one in which its principal office was located. ${ }^{40}$ And although the possibility of uncontrolled expansion in a state already marked by the corporation's greatest growth may not immediately appear a serious problem, holding companies are in fact anxious to expand in just such states and would probably be quick to take advantage of

stitutional question whether a state has the right to condition ownership of stock in a national bank. N.Y. Times, May 5, 1957, § 3, p. 1, col. 8. But New York is, consistent with $\S 7$, exercising its control over the franchise powers of corporations, not acting directly on national bank stock.

37. 70 STAT. 135 (1956), 12 U.S.C.A. \$ 1842 (d) (1957).

38. Throughout the hearings preceding passage of the act, "place of operations" was used to describe the states in which subsidiary banks were located. See, e.g., Hearings, supra note 10 , at 50 ; Hearings, supra note 15 , at 113. Thus, "place of principal operations" would describe the state in which the subsidiaries were most numerous. The commentators have made no attempt to clarify the meaning of the passage quoted in text. They have referred to the situs state variously as that of the holding company's: (1) "principal place of business," Comment, 9 Stan. L. Rev. 333, 338 (1957) ; (2) "principal office," Note, 31 St. John's L. Rev. 146, 151 (1956); (3) "home state," Nadler, The Banking Struation in New York State 121 (1956); (4) "principal operations," M. A. Schapiro \& Co., The Truple Banking System 28 (1956).

39. See Hearings, supra note 10 , at $128-29$; cf. proposals of the American Bankers Association, $i d$. at $289,292-93$.

40. If the corporation chose the state in which its principal office was located, it would be doing more business than merely holding bank stock and thus be subject to state regulation. See text at note 30 supra. 
the loophole allowing them to do so at will. ${ }^{41}$ By issuing regulations denying the choice between alternative situs states to the corporation, however, the Board can obviate this difficulty, since it would always be able to choose a residence permitting state control and thus insure that the declared policy of the act would be effectuated.

More important are the unique problems of federalism which will result from the means Congress has employed to give effect to state policy. Section 3(d) does not allow direct regulation by the states of foreign corporate expansion within their borders. Rather, it grants them indirect control by adopting as the governing federal law the provisions of state law regulating foreign corporate acquisition of state-chartered banks. And the section presumes that absent express state legislation, no foreign penetration would be permissible. ${ }^{42}$ This legislative delegation to the states, patterned on the McFadden Act, does not raise constitutional problems. Although the states fix expansion standards, the federal law adopts and applies them. And as Congress has absolute authority to regulate banking, it properly may implement these powers by adopting the provisions of state legislation..$^{43}$ Instead, the problems inherent in the legislation result from the fact that once state expansion policy is crystallized into federal law, all state contact with the administration of that policy vanishes. Although the states have jurisdiction specifically preserved by section 7 to proceed upon violation of their own laws, they have no power to initiate proceedings under the legislation incorporated by section 3(d). For without express congressional authorization, states may proceed neither civilly nor crim-

41. Transamerica Corporation, for example, after acquiring subsidiary banks in several states, expanded in California, the state in which its subsidiaries were most numerous prior to expanding in any other state. And when Transamerica began expanding in other states, it continued to expand in California at a significantly greater rate. See Moopy's, Manual of Investaients 968-69 (1954) (hereinafter cited as Moody's).

Some of the California acquisitions were accomplished through branching. Compare Moody's S64 (1946), with Moody's 968-69 (1957). In a state stringently regulating branching, of course, the holding company would have to resort to new acquisitions in order to expand.

42. Only when the state has expressly legislated to authorize out-of-state holding company acquisition of a state bank may the Board approve any foreign holding company acquisition. See $\$ 3$ (d), note 26 supra. As to the meaning of "expressly legislated," see note 50 infra.

43. The constitutional grant to Congress of "all legislative powers" has been judicially interpreted to forbid delegation of such powers to the executive or judicial branches of the federal government, or to any other governmental body. Jefferson, The Supreme Court and State Separation and Delegation of Powers, 44 CoLuM. L. REv. 1 (1944).

Delegation of effective control by adoption of the law of another jurisdiction does not violate this principle. Hanover Nat'l Bank v. Moyses, 186 U.S. 181, 190 (1902) (bankruptcy); Phillips v. Commissioner, 283 U.S. 589 (1931) (taxation); Permissive Linits of Delegation of Legislative Pozver, Annot., 79 L. Ed. 474, 507-09 (1934) ; Mermin, "Cooperative Federalism" Again: State and Municipal Legislation Penalizing Violation of Existing and Future Federal Requirements: I, 57 YaLE L.J. 1, 4-26 (1947); see note 46 infra. 
inally to enforce federal law.44 And though the standards of section 3(d) are adopted by reference to state legislation, the resulting law is federal. Thus the act provides for federal action upon willful violation of its terms, and the penalties prescribed are to be imposed in criminal proceedings brought by the Attorney General of the United States. ${ }^{45}$

But the states are unable to insure that their policies will be respected in federal enforcement of section 3(d). Since domestic interpretations of enactments adopted by reference are not incorporated into the federal law, the Board and the courts applying section 3(d) will not be bound by state constructions of such enactments. ${ }^{46}$ And though the states have substantial interest

44. A federal criminal statute must specifically authorize state action for a state to assist in its enforcement. Gambino v. United States, 275 U.S. 310 (1927) (prohibition); Holmgren v. United States, 217 U.S. 509 (1910) (naturalization). Nor may a state enforce federal regulatory law through civil process without federal consent. McClung v. Silliman, 19 U.S. (6 Wheat.) 598 (1821) (state court lacks authority to issue mandamus to federal officer); Armand Schmoll, Inc. v. Federal Reserve Bank, 286 N.Y. 503, 37 N.E.2d 225 (1941), cert. denied, 315 U.S. 818 (1942) (state not permitted to mandamus a Federal Reserve Bank to perform its statutory duty of determining and reporting a buying rate); Attorney Gen. ex rel. State Banking Comm'r v. National Bank, 338 Mich. 610, 61 N.W.2d 804 (1.953) (state attorney general lacks authority to bring quo warranto proceedings in state court to challenge national bank's right to establish a state forbididen branch). The Michigan court distinguished cases allowing state enforcement on the ground that Congress' leaving the matter to be governed by state law constituted a valid delegation. See, e.g., Ex parte Worcester County Nat'l Bank, 279 U.S. 347, 359-60 (1929) (trust powers of state bank consolidated into national bank are continued as latter's only when "not in contravention of state law") ; First Nat'1 Bank v. Fellows, 244 U.S. 416 (1917) (same). And it held the subject governed by federal law even though such law was based on state provisions. See text at note 33 supra; note 28 supra. See, generally, Note, Limitations on State Judicial Interference with Federal Activities, 51 CoLUM. L. REv. 84, 91-94 (1951).

45. 70 STat. 138 (1956), 12 U.S.C.A. § 1847 (1957), Even without such specific provision, the Board could compel holding company obedience by exercising its power to revoke the "voting permit" required of holding companies to vote their stock in national and member banks. See note 16 sipra. The ultimate sanction for flouting Board authority is revocation of the subsidiary banks' membership in the federal reserve system. 48 STAT. 186 (1933), as amended, 12 U.S.C. \& 61 (1952).

The Board requested enforcement by the Department of Justice with criminal penalties for violation, rather than by the administering agency. Hearings, supra note 15 , at 14 . And it did not contemplate making advisory determinations of whether a transaction would violate the act. Hearings, supra note 10, at 61. Lack of independent power in the Board, however, may hamper enforcement, since the Attorney General can penalize only willful violations, and good faith infractions may thus escape correction. 70 STAт. 138 (1956), 12 U.S.C.A. \& 1847 (1957). Compare the use of supoena power, mandamus, injunction and restraining order authorized to the administering agency in the Public Utility Holding Company Act of 1935, 49 STAr. 831, as amended, 15 U.S.C. \& 79r (1952).

46. A state's reading of its federally adopted law is not controlling. See HART \& Wechsler, The Federal Courts and the Federal System $456-57$ (1953). The Assimilated Crimes Act, REv. STAT. $\$ 5391$ (1875), as amended, 18 U.S.C. $\$ 13$ (1952), adopts state law by reference. Acts done in areas under the jurisdiction of the federal government, such as army reservations or federal buildings, which would be punishable under 
in insuring the applicability of their laws and in preserving their intended interpretations, they do not meet the requirements of the provisions authorizing judicial review and thus cannot challenge Board rulings. ${ }^{47}$ Accordingly,

state law, are made federal offenses subject to the same penalties. In Johnson $\mathbf{v}$ Yellow Cab Transit Co., 321 U.S. 383 (1944), Oklahoma, a dry state, had seized liquor in transit to an army post within its jurisdiction and claimed an Assimilated Crimes Act violation. The Supreme Court said: "That broad question, [violation of the Assimilated Crimes Act] though some parts of it involve a consideration of the proper scope of the state law adopted by the federal government, is in the final analysis a question of the correct interpretation of a federal criminal statute, and therefore an issue upon which federal courts are not bound by the rulings of the state courts." Id. at 391. See also AfcCoy v. Pescor, 145 F.2d 260, 262 (8th Cir. 1944) (state decision on sufficiencies of indictment not controlling in Assimilated Crimes Act prosecution); cf. 54 Mfrcr. L. Rev. 851 (1956).

47. Section 9 of the act, which provides for judicial review of Board rulings, provides that: "Any party aggrieved by an order of the Board under this Act may obtain a revicw of such order in the United States Court of Appeals. ..." 70 STAт. 138 (1956), 12 U.S. C.A. \& 1848 (1957). A party who has suffered an actual or threatened deprivation of a legal right meets the requirement of having been aggrieved. See Ollahoma v. United States Civil Service Comm'n, 330 U.S. 127, 136-37 (1947) ; Perkins v. Lukens Steel Co., 310 U.S. 113, 125 (1940) (requiring injury or threat to a personal right, as distinguished from the public's interest in the administration of the law); Doehla Grecting Cards, Inc. v. Summerfield, 116 F. Supp. 68, 72 (D.D.C. 1953) (requiring invasion of "private substantive legally protected interest"). In the absence of such harm, standing to securc judicial review is generally lacking. But the law determining standing is complex and confused. Davis, Adarinistrative Law 676-77 (1951). Compare Perkins v. Lukens Stecl, Co., supra (no standing since no injury to government supplier from wage determination affecting future bids); Alabama Power Co. v. Ickes, 302 U.S. 464 (1938) (no standing since only damage threatened to power companies was from lawful competition); Kansas City Power \& Light Co. v. McKay, 225 F.2d 924 (D.C. Cir. 1955), cert. denied, 350 U.S. 884 (1955) (same), with United States v. Storer Broadcasting Co., 351 U.S. 192 (1956) (standing because regulations limited future expansion); FCC v. Sanders Bros. Radio Station, 309 U.S. 470 (1940) (standing since radio station funancially injured by issuance of license to competitor).

The interest required to secure review has been found on slight foundation. E.g., Oklahoma v. United States Civil Service Comm'n, supra (state could obtain review of determination that its highway employee violated Hatch Act, since determination would result in withholding portion of federal highway funds, and state found to have legally enforceable right to receive allocated grants without unlawful deductions). Although it might be argued that a state seeking review of a Board determination under the Bank Holding Company Act has a legal right created by $\S 3(d)$ to refuse or permit holding company entry and that an improper Board interpretation is an infringement of this right, such state would probably not have even the interest found in Oklalomo. For the interest invaded there, as well as that involved in the authorities collected supro, was financial, and the interest under $\S 3(d)$ cannot be so rationalized. And even if the state's interest were claimed to be regulatory, the same result would be dictated by the fact that the law adopted by $\S 3(\mathrm{~d})$ is federal not state. See text at note 45 supro. ALorcover, the Bank: Holding Company Act does not require a state to be admitted as a party. See $\$ 3$ (b), 70 STAT. 134 (1956), 12 U.S.C.A. \& 1842(b) (1957). And, even if the Board allowed a state to intervene, the state might still be unable to secure judicial review. Sec, c.g., Boston Tow Boat Co. v. United States, 321 U.S. 632 (1944); Davis, Adscisistrative Law 689-91 (1951).

Under the act, only an "order" of the Board can be reviewed. See $\S 9$, sipro. But 
where a holding company has effected an acquisition without obtaining the requisite approval, ${ }^{48}$ where the Board has interpreted an incorporated law in a manner which conflicts with state intent ${ }^{49}$ and where in like situations domestic banking may be materially influenced by Board decisions, ${ }^{\text {b0 }}$ the state

review may not reach all orders since many will not be based on hearings producing reviewable records. See 9 STAN. L. Rev. 333, $342 \mathrm{n} .93$ (1957) ; Developments in the LawRemedies Against the United States and Its Officials, 70 Harv. L. REv. 827, 908 (1957).

Review may also be had under $\$ 10$ of the Administrative Procedure Act, 60 STat. 243 (1946), 5 U.S.C. $\$ 1009$ (1952) (including actions for declaratory judgments and suits for preventive or mandatory injunctions). But, again, the requirements of legal right or interest must be met. Atchison, T. \& S.F. Ry. v. United States, 130 F. Supp. 76, 78 (E.D. Mo.), aff'd per curiam, 350 U.S. 892 (1955) ; Kansas City Power \& Light Co. v. McKay, supra. See Developments in the Law-Rcmedies Against the United States and Its Officials, 70 HARv. L. REv. 827, 920 n.657 (1957). Since Board findings of fact supported by substantial evidence are conclusive, a holding that state intent is a question of fact would limit the scope of review on the propriety of the Board's interpretation. 70 StAT. 139 (1956), 12 U.S.C.A. $\$ 1848$ (1957). For a comprehensive treatment of review of administrative action, see Developments in the Lari-Remedies Against the United States and Its Officials, 70 Harv. L. Rev. 827, 910-23; Davis, Administrative LaW $\$ \$ 199-229,234-57$ (1951).

48. The act is unclear as to whether a holding company is required to have obtained Board approval prior to effecting certain types of acquisitions. Section 3(a) states:

"It shall be unlawful except with the prior approval of the Board (1) for any action to be taken which results in a company becoming a bank holding company under section 2(a) of this Act; (2) for any bank holding company to acquire direct or indirect ownership or control of any voting shares of any bank if, after such acquisition, such company will directly or indirectly own or control more than 5 per centum of the voting shares of such bank; (3) for any bank holding company or subsidiary thereof, other than a bank, to acquire all or substantially all of the assets of a bank; or for any bank holding company to merge or consolidate with any other bank holding company...."

70 STAT. 134 (1956), 12 U.S.C.A. \$ 1842(a) (1957). Thus, whether bank stock dividends may be acquired without prior approval of the Board is uncertain. Cf. the New York Bank Holding Companies Act which expressly excepts these dividends from acquisition restrictions. N.Y. BANKIng LAW $\$ 142$; see note 36 supra. And the acquisition by a subsidiary bank of all the assets of another bank without Board approval also may or may not be a violation. For while $\$ 3(a)(3)$ appears to allow this transaction, such interpretation might conflict with $\S 3$ (a) (2) which requires that a holding company seek approval prior to direct or indirect acquisition of more than $5 \%$ of the voting shares of a bank.

49. The Illinois Bank Holding Corporation Act, Ilt. ANN. Stat. c. 161/2, $\$ \$ 64-6 \$$ (Smith-Hurd Supp. 1956), for example, forbids future acquisition by a holding company, including a foreign holding company, of more than $15 \%$ of the stock of two or more banks. Whether and to what extent this provision specifically, rather than impliedly, authorizes foreign corporate penetration as required by $\S 3(\mathrm{~d})$, is likely to be the subject of conflicting interpretation. In an analogous situation under the McFadden Act which also requires specific language, similar legislation was found to give the necessary authorization. 37 OPs. Atr'y GeN. 325 (1933).

50. The transactions encompassed by $\S 3$ (a) may be of considerable interest to the state in which the participating banks and holding companies are located. In $\S 3(\mathrm{c})$ Congress recognizes local interest by specifying that one of the factors which the Board 
can only request that federal action conform to domestic policy. And this request may be neglected or ignored. ${ }^{51}$

Nevertheless, full implementation of state expansion policy may be achieved under the act. The limited role of the states in administering the standards of section $3(d)$ is in part dictated by constitutional limitations on congressional delegation to the states. ${ }^{52}$ In the instant legislation, Congress might have given the states more executive authority. But the exact extent of permissible control in this area can not be ascertained, since the boundaries of legitimate delega. tion generally are unclear. ${ }^{53}$ In any event, the congressional purpose to achieve effective holding company control is apparent. With some exceptions, ${ }^{54}$ this end is sought by means of federal regulation through Board supervision. How-

must take into account when passing on an acquisition is "the convenience, needs, and welfare of the communities and area concerned." See text at note 25 supra; 70 STAT. 135 (1956), 12 U.S.C.A. § 1842(c) (1957). Moreover, $\S 3$ (b) requires that the Board seek, though not necessarily follow, the advice of the appropriate state official when a state bank is to be acquired. Ibid.

51. A state can be assured that its policies will be effected only if it has passed no enabling legisiation. For under this circumstance, due to the presumption built into $\$ 3$ (d), the Board cannot approve foreign penetration. But while a state may consciously adopt such an absolute policy against holding company acquisition where the concentration in its banking facilities is high, c.g. New York, see note 36 supra, most states have not and probably will not take such a restrictive attitude. Even Illinois, a citadel of home-owned banking, merely restricts, but does not exclude, foreign bank holding companie's. Georgia has identical legislation. Ga. S. 30, Jan.-Feb. session, approved, Feb. 27, 1956; see 102 Cong. Rec. 6752-53 (1956). Many states have not even attempted to limit concentration through anti-branch laws. In fact, Nevada, prompted by widespread bank failures during the depression, officially invited a bank holding company (Transamerica) to enter and stabilize its banks. Hearings Before a Subcommittee of the Senate Committee on Banking and Currency, 81st Cong., 2d Sess. 186-87 (1950). Moreover, a state already containing powerful holding companies would appear not unlikely to prefer to maintain competition by authorizing the entrance of other holding companies. But see 9 STAN. L. REv. 333,338 (1957).

52. As to delegation by adoption of standards set out by another governmental unit, see note 43 supra; Mermin, supra note 43 , at 23 n.57. Delegation of authority to regulate in an otherwise federal field may also be based on a theory of congressional "consent" or "divestment of protection." Prudential Ins. Co. v. Benjamin, 328 U.S. 408 (1946) (Congress may consent to state insurance regulation otherwise invalid for discriminating against interstate commerce); Whitfield v. Ohio, 297 U.S. 431. (1936) (power to enforce laws forbidding sale of convict-made goods in interstate commerce was granted to states by divesting such goods of the protection of interstate commerce); In re Rahrer, 140 U.S. 545,564 (1891) (power to enforce prohibition laws against liquor in interstate commerce was given to states by divesting protection). See Mermin, supra note 43 , at $21,22 \&$ nn.56, 57, for an exhaustive discussion of the consent and divestment theories.

53. For discussion of the general problem see, Jaffe, An Essay on Delegation of Legislative Power, 47 Colvar. L. Rev. 359, 561 (1947) ; Mermin, supra note 43; Jacoby, Delegation of Powers and Judicial Review: A Study in Comparative Law, 36 Colum. L. Rev. 871 (1936). See also 54 Mich. L. Rev. 851 (1956).

54. See note 49 supra. Subsidiary banks would seem able to merge unfettered by the restrictions of $\$ 3(\mathrm{a})(2)$. See Note, 9 Stan. L. Rev. 333, 348-50 (1957) ; M. A. Schapiro \& Co., The Triple Banking System 27 (1956). But see note 48 supra. 
ever, the policy of sections $3(d)$ and 7 is also of great import. Congress has expressed its desire to let local policy govern holding company expansion unless clearly unsuited to broader national interests. And this result can be accomplished within the framework of the act if the federal authorities recognize the value of state assistance. Once the state has performed the integral function of enacting the legislation forming the basis of section $3(d)$, its remaining role is advisory. The Board and the courts should avail themselves of this role to insure that the expansion policy they apply is in fact that formulated by the state and intended by Congress. 